nhiên luôn là cần thiết việc rà soát hoat động phân loại thuốc theo VEN và giám sát chặt chẽ các thuổc nhóm $\mathrm{N}$ đã sử dụng tại bệnh viện.

\section{KẾT LUÂN}

Giai đoạn 2019-2020, Bênh viện Nội Tiết TW đã sử dụng nhiều nhất nhóm thuốc Hormon và các thuốc tác động vào hệ nội tiết (chiếm 42,27\% giá trị sử dụng); thuốc nhập khẩu chiếm giá trị sử dụng cao $(89,58 \%)$; thuốc biệt dược gốc có giá trị sử dụng chiếm $56,07 \%$. Phân tích $A B C / V E N$ cho thãy cơ cấu mua sắm thuốc tại bênh viện là hợp lý, không có nhóm thuốc Aì Các thuốc nhóm $\mathrm{N}$ sử dụng ít (chiếm 1,59\% giá trị sử dụng).

\section{TÀI LIÊU THAM KHẢO}

1. Bênh viện Nôi Tiết TW (2020), Kỷ yếu 50 năm thành lập bệnh viện,
2. Bộ Y tế (2013), Thông tư $21 / 2013 / T T-B Y T$ ngày 8/8/2013 Quy định về tổ chức và hoạt động của Hô̂i đồng Thuốc và điều trị trong bênh viên

3. Bổ Y tế (2018), Thông tư số $19 / 2018 / T$ T'-BYT ngày 30/8/2018 Ban hành Danh muc thuốc thiết yếu

4. Lê Thị Hằng (2020), Phân tích danh mục thuốc sử dung tai Bênh viên Hữu Nghi năm 2018; Luân văn thac sĩ dược hoc - Trường Đai học Dược Hà Nội

5. Lê Thi Tuyết Mai (2018), Phân tích danh muc thuốc sử dụng tại Bệnh viện Bạch Mai năm 2016; Luận văn thạc sĩ dược học - Trường Đại học Dược Hà Nôi

6. Nguyễn Thanh Uyên (2019), Phân tích danh muc thuốc sử dung tai Bênh viên Nhi TW năm 2018; Luận văn thạc sĩ dược học - Trường Đại học Dước Hà Nôi

7. Tổ chức Y tế Thế giới (2004), Hội đồng thuốc và điêuu tri - Cẩm nang hướng dân thực hành, trang 87-89,

8. WHO (2017); Model Lists of Essential Medicines (EML) $20^{\text {th }}$

\title{
NHẬN XÉT ĐĂC ĐIỂM LÂM SÀNG, CÂN LÂM SÀNG CỦA BỆNH NHÂN UNG THƯ DA DÀY ĐIỀU TRI BỔ TRƠ PHÁC ĐỒ CAPEOX TẠI BỆNH VIỆN QUÂN Y 103 VÀ BỆNH VIỆN BẠCH MAI
}

\author{
Hà Văn Trí1 ${ }^{1}$ Phạm Ngọc Điệp ${ }^{1}$ \\ Nghiêm Thị Minh Châu ${ }^{1}$, Phạm Cẩm Phương ${ }^{2}$
}

\section{TÓM TẮT}

Mục tiêu: Nhân xét đăc điểm lâm sàng, cân lâm sàng của các bệnh nhân ung thư da dày được điều trị bổ trợ bằng phác đồ CapeOx tai bệnh viện Quân Y 103 và bệnh viện Bạch Mai năm 2018-2020. Đối tương nghiên cứu: 40 bênh nhân ung thư da dày giai đoạn IB-III được điều trị bổ trợ bằng phác đồ CapeOx tai bênh viên 103 và bệnh viển Bach Mai năm 2018-2020. Các chỉ tiêu nghiên cứu gồm: tuổi, giới, tiền sử bênh lý da dày, triêu chứng lâm sàng, nồng đố CA72-4 trước phẫu thuật, thời gian chẩn đoán xác định bênh, vị trí tổn thương, thể mô bênh học, giai đoạn bệnh. Phương pháp: Nghiên cứu mô tả cắt ngang. Kết quả: Tuổi trung bình mắc bệnh là $57,4 \pm$ 10,4 ; tỷ lệ nam/nữ 3,44/1. Bênh hay gặp nhất trong độ tuổi từ 50 đến dưới 60 tuối. Triệu chứng lâm sàng đa dang và không đăc hiệu, trong đó triệu chứng thường gặp nhất là đau bụng thượng vị, chiếm $92,5 \%$, đây cũng là triêu chứng chủ yếu làm người bệnh đi khám; nhóm bệnh nhân không có tiền sử bểnh lý da dày chiểm tỷ ị̂̂ cao $45 \%$, nồng độ CA72-4 trước phẫu thuật tăng ở 45\% các trường hợp, giai

${ }^{1}$ Bệnh viện Quân Y 103

2 TT YHHN \& UB - Bênh viên Bach Mai

Chịu trách nhiệm chính: Hà Văn Trí

Email: dr.havantri1994@gmail.com

Ngày nhận bài: 11.01.2021

Ngày phản biên khoa hoc: 18.3.2021

Ngày duyệt bài: 29.3.2021 đoạn III có tỷ lệ tăng CA72-4 cao hơn so với giai đoạn IB-IIB với $p<0,05$. Vị trí tổn thương chủ yểu gặp ở vùng hang-môn vị $(60 \%)$ và bờ cong nhỏ của da dày $(32,5 \%)$. Phần lớn có thể mô học ung thư biểu mô tuyến kém biêtt hóa $(45 \%)$. Giai đoạn IIA và IIIA là giai đoạn phổ biến nhất, cùng chiếm $27,5 \%$. Số bệnh nhân giai đoan IB-IIA cao hơn số bệnh nhân giai đoạn IIIB-IIIC. Kết luân: Đặc điểm lâm sàng, cận lâm sàng bênh nhân ung thư dạ dày điều trị bố trợ bằng phác đồ CapeOx tai bệnh viện 103 và bệnh viện Bach Mai chưa khác biệt nhiều so với các nghiên cứu trước đây.

Tư khóa: Hóa trị bổ trơ ung thư da dày, phác đồ CapeOx, lâm sàng ung thư dạ dày.

\section{SUMMARY}

DESCRIBE CLINICAL AND SUBCLINICAL CHARACTERISTICS OF GASTRIC CANCER PATIENTS WHO RECEIVED ADJUVANT CHEMOTHERAPY USING CAPEOX REGIMEN AT MILITARY HOSPITAL 103 AND BACH MAI HOSPITAL

Objective: Describe clinical and subclinical characteristics of gastric cancer patients who received CapeOx adjuvant regimen at 103 military hospital and Bach Mai hospital from 2018-2020. Subjects: 40 gastric cancer patients who received CapeOx adjuvant regimen at the Military hospital 103 and Bach Mai hospital from 2018-2020. Research indexes include age, sex, history of gastric diseases, clinical symptoms, preoperative CA72-4 concentration, time of 
diagnosis, site of tumor, type of histopathology, stage of disease. Methods: Cross-sectional study. Results: The median age of 40 patients was $57.4 \pm 10.4$ male/female ratio was 3.44/1. Clinical symptoms varied and nonspecific, of which the most common symptom was epigastric abdominal pain, accounting for $92.5 \%$, it is also the main reason of patients to take health check; $45 \%$ of patients had no previous history of gastric diseases. Lesion sites were mainly found in the pyloric region (60\%) and lesser curvature of the gastric (32.5\%). The poorly differentiated subtype had the highest percentage (45\%). Stage IIA and IIIA were the most popular, each stage accounted for $27.5 \%$ the number of patients with stage IB-IIA is higher than that of stage IIIB-IIIC. Conclusion: The clinical and subclinical features of gastric cancer patients who received CapeOx adjuvant regimen at 103 military hospital and Bach Mai hospital from 20182020, were quite similar to previous studies.

Keyword: Clinical gastric cancer, adjuvant chemotherapy of gastric cancer, CapeOx regimen

\section{I. ĐẶT VẤN ĐỀ}

Ung thư dạ dày là một trong những loại ung thư phổ biến nhất trên thế giới. Tại Việt Nam theo Globocan 2018, đây là loại ung thư đứng hàng thứ 3 về tỷ lệ mới mắc và tử vong [1]. Hiện nay đối với ung thư dạ dày giai đoạn IB, II, III việc chẩn đoán sớm, phẫu thuật đảm bảo triệt căn kết hợp với lựa chọn phác đồ hóa chất bổ trợ phù hợp, hiệu quả như CapeOx, FOLFOX, EOX... là những yếu tố cơ bản giúp kéo dài thời thời gian sống thêm cho người bệnh. Cùng với sự phát triển của các kỹ thuật chẩn đoán và sự nâng cao nhận thức của người bệnh, nhiều bệnh nhân đã được chẩn đoán bệnh ở giai đoạn sớm vì vậy một số triệu chứng lâm sàng, cận lâm sàng của bệnh nhân có thể thay đổi. Việc tìm hiểu các đặc điểm lâm sàng, cận lâm sàng của bệnh nhân ung thư dạ dày có vai trò rất quan trọng, góp phần giúp ích trong việc chẩn đoán sớm, và cung cấp thêm thông tin để việc điêu trị đạt kết quả cao nhất. Đề tài này được tiến hành nhằm mục tiêu nhận xét các đặc điểm lâm sàng, cận lâm sàng của bệnh nhân ung thư dạ dày điều trị bổ trơ bằng phác đồ $\mathrm{CapeOx}$ tai bênh viện Quân Y 103 và bệnh viện Bạch Mai trong thời gian 2018-2020.

\section{II. ĐỐI TƯƠNGG VÀ PHƯƠNG PHÁP NGHIÊN CỨU}

2.1 Đối tượng nghiên cứu. 40 bệnh nhân ung thư da dày giai đoạn IB(T1N1M0), II, III được điều trị bổ trợ bằng phác đồ CapeOx tại Trung tâm ung bướu Bệnh viện Quân y 103 và trung tâm YHHN\&UB - Bệnh viện Bạch Mai trong năm 2018-2020. Phương pháp lấy cõ mẫu: toàn bộ. Tiêu chuẩn chọn: Giai đoạn IB(T1N1M0), II, III; đã phẫu thuật cắt dạ dày triệt căn + nạo vét hạch D2, mô bệnh học ung thư biểu mô, toàn trạng PS $\leq 2$.

\subsection{Phương pháp nghiên cứu}

- Nghiên cứu mô tả cắt ngang

- Các chỉ tiêu nghiên cứu: tuổi, giới, tiền sử bệnh lý dạ dày, triệu chứng lâm sàng, nồng độ CA72-4 trước phẫu thuật, thời gian chẩn đoán xác định bệnh, vị trí tổn thương, thể mô bệnh học, giai đoạn bệnh.

2.3 Phân tích số liệu: Sử dụng phần mềm thống kê SPSS 22.0, số liệu được trình bày dưới dạng giá trị trung bình, độ lệch chuẩn, tỷ lệ phần trăm.

2.4 Khía cạnh đạo đức nghiên cứu: Đảm bảo các qui định về y đức trong nghiên cứu y học

\section{KẾT QUẢ NGHIÊN CỨU VÀ BÀN LUÂN}

\section{1. Đăcc điểm tuổi, giới.}

Đặc điểm về tuổi giới của nhóm bệnh nhân nghiên cứu $(n=40)$

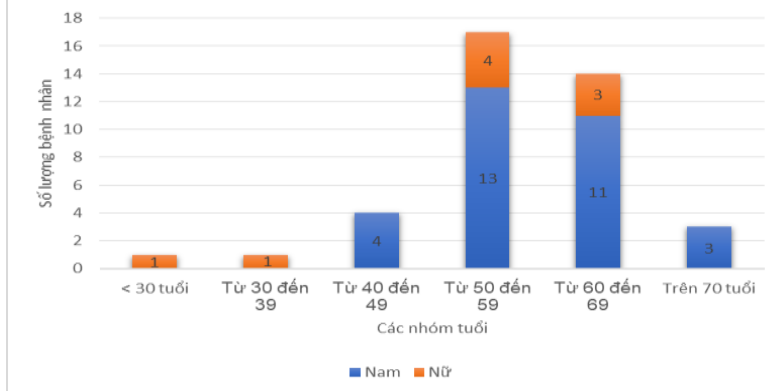

Biểu đồ 3.1 Đặc điểm tuổi - giới nhóm bệnh nhân nghiên cứu.

- Theo kết quả biểu đồ 3.1, tuổi trung bình của nhóm bênh nhân là $57,4 \pm 10,4$ (22-76). Hai nhóm tuổi thường gặp nhất là từ 50 đến dưới 60 (chiếm 42,5\%) và nhóm từ 60 đến dưới 70 tuổi chiếm 35\%. Nghiên cứu gồm 40 bệnh nhân trong đó có 31 bệnh nhân nam (chiếm 77,5\%) và có 9 bệnh nhân nữ (chiếm 22,5\%). Tỷ lệ nam/nũ: $31 / 9=3,44 / 1$.

- Độ tuổi mắc bệnh trong nghiên cứu này là phù hợp nhưng tỷ lệ nam/nữ có phần cao hơn so với một số nghiên cứu như: Vũ Quang Toản (2017) với tuổi trung bình là $53,3 \pm 9,7$ (27-74), độ tuổi 50-59 chiếm đa số với $48 \%$, tỷ lệ nam/nũ là 3,1/1 [2]. Barreto (2014) trong một nghiên cứu ở Ân Độ cũng gặp độ tuổi gần tương đương với độ tuổi trung bình 51 tuổi. $\mathrm{Nam} / \mathrm{nữ}=3 / 1$ [3]. Tỷ lệ nam/nữ của nghiên cứu này có phần cao hơn một số nghiên cứu khác có Iẽ một phần là do nghiên cứu được thực hiện ở 1 bệnh viện Quân đội thu dung điều trị số bệnh nhân nam nhiều hởn số bệnh nhân nữ.

\subsection{Tiền sử bệnh lý dạ dày}

Bảng 3.1 Tiền sử bệnh lý dạ dày 


\begin{tabular}{|c|c|c|}
\hline Tiền sử & $\begin{array}{c}\text { Số lượng } \\
\text { (n=40) }\end{array}$ & $\begin{array}{c}\text { Tỷ lệ } \\
\mathbf{0}\end{array}$ \\
\hline Không ghi nhận tiền sử & 18 & 45 \\
\hline Viêm dạ dày mạn tính & 15 & 37,5 \\
\hline Loét dạ dày & 6 & 15 \\
\hline Polyp dạ dày & 1 & 2,5 \\
\hline
\end{tabular}

- Tiên sử bệnh lý dạ dày: viêm dạ dày mạn tính, loét da dày, polyp da dày... đều là các yếu tố nguy cơ của ung thư da dày. Theo kết quả của bảng 3.1, nhóm bệnh nhân không có tiền sử bệnh lý da dày có tỷ lệ cao nhất chiếm 45\%, tiếp theo là nhóm bệnh nhân có tiền sử viêm dạ dày man tính chiếm 37,5\%. Kết quả này phù hợp với nghiên cứu của Đặng Thị Ngọc Dung (2019) trên 182 bệnh nhân ung thư da dày tại Việt Nam, nhóm không có tiền sử bệnh lý dạ dày cũng chiếm tỷ lệ cao nhất với 44,5\%; kế tiếp là nhóm viêm dạ dày mạn với 35,7\% [4].

- Như vậy có nhiểu trường hợp bệnh lý ung thư dạ dày vẫn tiến triển âm thầm ở những cơ thể không có tiền sử bệnh lý dạ dày, hoặc có tiên sử bệnh lý dạ dày nhẹ và bị bỏ qua, do đó cân thiết phải tiến hành việc xét nghiệm sàng lọc ung thư da dày đối với các trường hợp nguy cơ cao, kể cà những trường hợp cho rằng dạ dày của ho hoàn toàn "khỏe manh"

\subsection{Triêuu chứng lâm sàng}

\section{Bảng 3.2. Triệu chứng lâm sàng}

\begin{tabular}{|c|c|c|}
\hline Triệu chứng & $\begin{array}{c}\text { Số lượng bệnh } \\
\text { nhân(n=40) }\end{array}$ & $\begin{array}{c}\text { Tỷ lệ } \\
\mathbf{\%}\end{array}$ \\
\hline Đau bụng thượng vị & 37 & 92,5 \\
\hline Đâyy bụng, khó tiêu & 25 & 62,5 \\
\hline Ợ hơi, ợ chua & 23 & 57,5 \\
\hline Gây sút cân & 22 & 55 \\
\hline $\begin{array}{c}\text { Nôn máu, đi ngoài } \\
\text { phân đen }\end{array}$ & 8 & 20 \\
\hline
\end{tabular}

Theo kết quả của bảng 3.2 các triệu chứng lâm sàng biểu hiện đa dạng và không đặc hiệu: đau bụng thượng vị chiếm 92,5\%; đây bụng, khó tiều $62,5 \%$; Ơ hơi, ơ chua $57,5 \%$; gây sút cân chiếm 55\%; buồn nôn, nôn 27,5\%; mệt mỏi $27,5 \%$; nôn máu, đi ngoài phân đen $20 \%$.

Trong nghiên cứu này biểu hiện chính khiến bệnh nhân đi khám là đau bụng vùng thượng vị. Tuy nhiên, triệu chứng này cũng rất khó phân biệt với các bệnh lý khác và đặc biệt là viêm loét dạ dày là bệnh lành tính thường gặp. Đa phân các bềnh nhân được điêu trị theo hướng viêm, loét dạ dày trước khi đến viện. Khi các triệu chứng đau điển hình thì thường bệnh đã ở giai đoạn muộn, u xâm lấn qua các lớp của thành dạ dày.

Từ đặc điểm về độ tuổi mắc bệnh, cân phải nghĩ tới bệnh lý ung thư dạ dày ở một bệnh nhân trong độ tuổi từ 50-70 khi tới khám vì các triệu chứng của bệnh lý dạ dày, dù người bệnh có hay không có tiền sử bệnh lý dạ dày.

3.4. Nông độ CA72-4 trước phẫu thuật Bảng 3.3 Nồng đố CA72-4 trước phẫu thuât Nồng độ CA 72-4

\begin{tabular}{|c|c|c|c|}
\hline \multicolumn{2}{|c|}{$(\mathrm{U} / \mathrm{ml})$} & \multicolumn{2}{|c|}{$(n=40)$} \\
\hline \multicolumn{2}{|c|}{ Bình thường $(0-8,2)$} & \multicolumn{2}{|c|}{22} \\
\hline \multicolumn{2}{|c|}{ Tăng $(>8,2)$} & \multicolumn{2}{|c|}{18} \\
\hline \multicolumn{4}{|c|}{ Giá trị trung bình: $X=10,7 \pm 11,4(\mathrm{U} / \mathrm{ml})$} \\
\hline $\begin{array}{c}\text { Giai } \\
\text { đoạn }\end{array}$ & $\begin{array}{l}\text { Số } \\
\text { bệnh } \\
\text { nhân }\end{array}$ & $\begin{array}{c}\text { Số trường } \\
\text { hợp tăng } \\
\text { CA72-4 }\end{array}$ & p \\
\hline IB-IIB & 21 & 6 & \multirow{2}{*}{$p<0,05$} \\
\hline III & 19 & 12 & \\
\hline
\end{tabular}

- CA72-4 là một marker quan trọng trong ung thư dạ dày. Theo kết quả của bảng $\mathbf{3 . 3}$ cho thấy, nông độ CA72-4 tăng ở 18 trường hợp (chiếm 45\%). Giá trị trung bình của nồng độ CA72-4 trước phẫu thuât là $10,7 \pm 11,4 \mathrm{U} / \mathrm{ml}$ $(0,78-56,4)$. Tỷ lệ bệnh nhân có tăng nồng độ CA72-4 ở giai đoạn III là 12/19 trường hợp, cao hơn có ý nghĩa thống kê so với tỷ lệ bệnh nhân tăng nồng độ CA72-4 ở giai đoạn IB-IIB (là $6 / 21)$ với $p<0,05$.

- Kết quả này khá phù hợp với nghiên cứu của Shimada và cộng sự năm 2014, khi phân tích 19 nghiên cứu với tổng số 2774 bệnh nhân, thâyy tỷ lệ tăng nồng độ CA72-4 gặp ở 16-70\% các trường hợp tùy nghiên cứu, hay gặp trong khoảng 30-40\%. Có sự tương quan rõ rệt giữa tỷ lệ tăng CA72-4 và giai đoạn bệnh, trong đó tỷ lệ tăng CA72-4 theo các giai đoạn lân lượt là: giai đoạn I=12\%; giai đoạn II=15,6\%; giai đoạn III=36,7\%; giai đoạn IV là 49,6\%[5].

- Tỷ lệ bệnh nhân có tăng nồng độ CA72-4 tăng dân theo sự tăng của giai đoạn bệnh gợi ý có sự liên quan giữa số lượng và sự đa dạng của các tế bào ung thư (do tính không đồng nhất của bệnh ung thư) với nồng độ CA72-4 huyết tương. Những bệnh nhân ung thư dạ dày giai đoạn muộn có số lượng tế bào ung thư lớn hơn và sự đa dạng các tế bào ung thư có lẽ cũng nhiều hơn so với những bênh nhân ung thư dày giai đoạn sớm, đây có thể là nguyên nhân làm nồng độ CA72-4 ở các bệnh nhân ung thư dạ dày giai đoạn muộn tăng ở tỷ lệ cao hơn.

3.5. Thời gian có chẩn đoán xác định bênh.

Bảng 3.4. Thởi gian chẩn đoán xác định bệnh

\begin{tabular}{|c|c|c|}
\hline $\begin{array}{c}\text { Thời gian chẩn đoán } \\
\text { xác định bệnh }\end{array}$ & Số BN & Tỷ lệ \% \\
\hline Dưới 3 tháng & 27 & 67.5 \\
\hline Từ 3 đến dưới 6 tháng & 7 & 17.5 \\
\hline Từ 6 đến dưới 12 tháng & 3 & 7.5 \\
\hline
\end{tabular}




\begin{tabular}{|c|c|c|}
\hline Trên 12 tháng & 3 & 7.5 \\
\hline Tổng số & 40 & 100 \\
\hline
\end{tabular}

- Theo kết quả của bảng 3.4, thời gian chẩn đoán xác định bênh (từ lúc có triệu chứng bất thường đầu tiên đến khi có chẩn đoán xác định) của nghiên cứu này là $3,7 \pm 4,2$ tháng (1 tuầ18 tháng). Thời gian này là thấp hơn so với thời gian trung bình của môt số nghiên cứu như Lê Thành Trung (2011) với 4,6 \pm 3,1 tháng [6], Vũ Quang Toản (2017) 5,9 $\pm 3,5$ tháng [1]. Kết quả này có lẽ là do bệnh nhân đã quan tâm hơn đối với sức khỏe của họ và việc xét nghiệm chẩn đoán bênh đã tốt hơn so với trước.

Thời gian này ở nhóm không có tiền sử bệnh lý dạ dày là $2,3 \pm 1,7$ thấp hớn so với nhóm có tiền sử bệnh lý dạ dày là $4,9 \pm 5,3$ với $p<0,05$. Điều này là phù hợp, có thể giải thích do ở những bệnh nhân có tiền sử bệnh lý dạ dày họ thường chủ quan hơn, khi triệu chứng đã biểu hiện rõ thì ho mới đi khám.

\subsection{Vị trí tổn thương}

\section{Bảng 3.5. Vị trí tổn thương}

\begin{tabular}{|c|c|c|}
\hline Vị trí tốn thương & Số BN & Tỷ lệ \% \\
\hline Tâm vị - phình vị & 2 & 5 \\
\hline Thân vị & 0 & 0 \\
\hline Bờ cong nhỏ & 13 & 32.5 \\
\hline Bờ cong lớn & 1 & 2.5 \\
\hline Hang vị - môn vị & 24 & 60.0 \\
\hline Tống số & $\mathbf{4 0}$ & $\mathbf{1 0 0}$ \\
\hline
\end{tabular}

Theo kết quả của bảng 3.5, Trong nghiên cứu này vị trí $u$ thường gặp nhất là vùng hang môn vị chiếm $60 \%$, kế tiếp là bờ cong nhỏ chiếm $32,5 \%$. Kết quả này cũng phù hợp với một số tác giả trong nước khi vị trí u ở hang-môn vị và bờ cong nhỏ trong nghiên cứu của Vũ Quang Toản (2017) lần lượt là $67,8 \%$ và $21,7 \%[1]$, Trịnh Thị Hoa (2009) lần lượt là $64,2 \%$ và $33 \%$ [7]. Vị trí u chủ yếu xuất hiện ở vùng hang-môn vị, bờ cong nhỏ có lẽ là do tại đây có nhiều yếu tố nguy cơ để phát sinh ung thư dạ dày như chịu ảnh hưởng lớn của chế độ ăn và sư cư trú thường xuyên của vi khuẩn HP (nếu nhiễm) tại 2 vùng này.

3.7 Thể mô bệnh học

Bảng 3.6 thể mô bềnh hoc

\begin{tabular}{|c|c|c|}
\hline Đặc điếm & Số BN & Tỷ lệ $\%$ \\
\hline UTBM tuyến & 35 & 87.5 \\
\hline Biệt hóa cao & 3 & 7.5 \\
\hline Biệt hóa vừa & 14 & 35 \\
\hline Kém biết hóa & 18 & 45 \\
\hline UTBM tế bào nhẩn & 5 & 12.5 \\
\hline Tống số & $\mathbf{4 0}$ & $\mathbf{1 0 0}$ \\
\hline
\end{tabular}

Từ kết quả bảng 3.6 cho thấy, ung thư biểu mô tuyến kém biệt hóa chiếm tỷ lệ cao nhất (45\%), kế tiếp là thể biệt hóa vừa (35\%).

Kết quả này là phù hợp với các nghiên cứu trong nước như Vũ Quang Toản (2017) với tỷ lệ ung thư biểu mô kém biệt hóa và biệt hóa vừa lân lướt là 38,8\%; 32,3\% [1]. Ngược lại, Trinh Hồng Sơn (2001) gặp loại biệt hóa cao nhiều nhất 40,85\%; loại biệt hóa vừa $26,8 \%$; loại kém biệt hóa $19,61 \%$ trong khi loại không biệt hóa là $12,47 \%[8]$. Sự khác biệt giữa nghiên cứu của chúng tôi với nghiên cứu của Trịnh Hồng Sơn (2001) một phần có lẽ là do 2 nghiên cứu được thực hiện ở hai địa điểm khác nhau và thời gian thực hiện cách nhau khá xa (khoảng gần 20 năm).

\subsection{Giai đoạn bệnh}

Bảng 3.7. Giai đoạn bệnh

\begin{tabular}{|c|c|c|}
\hline Giai đoạn & Số BN $\mathbf{~ ( n = 4 0 ) ~}$ & Tỷ lệ \% \\
\hline IB & 3 & 7,5 \\
\hline IIA & 11 & 27,5 \\
\hline IIB & 7 & 17,5 \\
\hline IIIA & 11 & 27,5 \\
\hline IIIB & 7 & 17,5 \\
\hline IIIC & 1 & 2,5 \\
\hline Tổng số & $\mathbf{4 0}$ & $\mathbf{1 0 0}$ \\
\hline
\end{tabular}

Do nghiên cứu được thực hiện trên nhóm bệnh nhân có chỉ định điều trị hóa chất bổ trợ, nển có giai đoạn bệnh từ IB-IIIC (kết quả được ghi ở bảng 3.4). Trong đó giai đoạn IIA, IIIA chiếm tỷ lệ cao nhất (cùng chiếm 27,5\%), tiếp theo là giai đoạn IIB và IIIB cùng chiếm $17,5 \%$, giai đoan IB chiếm $7,5 \%$, chỉ có 1 bênh nhân tương ứng với $2,5 \%$ ở giai đoan IIIC.

Tỷ lệ bệnh nhân được chẩn đoán ở giai đoạn IB-IIA là $35 \%$, cao hơn so với tỷ lệ bệnh nhẩn được chẩn đoán ở giai đoạn IIIB-IIIC với $20 \%$, kêt quả này có lẽ là nhờ vai trò của sự phát triển chung của hệ thống y tế, các kỹ thuật chẩn đoán và sự nâng cao nhận thức người bệnh.

\section{KẾT LUÂ̂N}

- Tuổi trung bình mắc bênh là $57,4 \pm 10,4$; bệnh hay gặp nhất ở độ tuổi từ 50 đến dưới 60 tuổi. Tỷ lệ nam/nữ 3,44/1. Nhóm bệnh nhân không có tiền sử bệnh lý dạ dày chiếm tỷ lệ cao (45\%). Triêu chứng lâm sàng đa dang, trong đó triệu chứng thường gặp nhất và là lý do chính để bệnh nhân đi khám là đau bụng thượng vị, chiếm 92,5\%.

- Nồng độ CA72-4 trước phẫu thuật tăng ở 45\% các trường hợp, giai đoạn III có tỷ lệ tăng nồng độ CA72-4 cao hơn giai đoạn IB-IIB với $p<0,05$. 
- Thời gian chẩn đoán xác định bệnh chủ yếu dưới 3 tháng, nhóm bệnh nhân không có tiền sử bệnh lý dạ dày có thời gian chẩn đoán ngắn hơn nhóm có tiền sử bệnh lý dạ dày $(2,3 \pm 1,7$ tháng so với $4,9 \pm 5,3$ tháng, $p<0,05)$.

- Tồn thương ung thư chủ yếu gặp ở vùng hang-môn vị $(60 \%)$ và bờ cong nhỏ của dạ dày $(32,5 \%)$. Phần lớn các trường hợp có thể mô bệnh học thuộc týp ung thư biểu mô tuyến kém biệt hóa $(45 \%)$. Giai đoạn bệnh IIA và IIIA chiếm tỷ lệ cao nhất (cùng chiếm 27,5\%); số bênh nhân giai đoạn IB-IIA cao hơn so với số bểnh nhân ở giai đoạn IIIB-IIIC.

Đặc điểm lâm sàng, cận lâm sàng bệnh nhân ung thư dạ dày điều trị bổ trợ bằng phác đồ CapeOx tai bênh viện 103 và bênh viên Bach Mai chưa khác biệt nhiều so với các nghiên cứu trước đây.

\section{TÀI LIÊU THAM KHẢO}

1. Ajani J.A., Gerdes H., Kleinberg L.R. và cộng sự. (2019). NCCN Guidelines Index Table of Contents Discussion. Gastric Cancer, 122.

2. Vũ Quang Toản (2017), Đánh giá kết quả điều tri ung thư da dày giai đoạn IIB-IIII (T4, NO-3, M0) bắng hóa chẩt bố trỡ EOX sau phẫu thuâat tai bênh viện K, (2013-2016), Luận văn Tiến sĩ Ỳ học, Trường Đại học Y Hà Nội.
3. Barreto SG, Batra S, Goel M et al (2014), Epirubicin, oxaliplatin, and capectabine is just as "MAGIC"al as epirubicin, cisplatin, and fluorouracil perioperative chemotherapy for resectable locally advanced gastro-oesophageal cancer, Journal of Cancer Research and Therapeutics, Vol. 10, No. 4, October-December, 2014, pp. 866-870

4. Ngoc Thi Dang D., Ngoc Thi Nguyen L., Thi Dang N. và cống sự. (2019). Quality of Life in Vietnamese Gastric Cancer Patients. BioMed Research International, 2019, e7167065, accessed: 01/01/2021.

5. Shimada H., Noie T., Ohashi M. và cộng sự. (2014). Clinical significance of serum tumor markers for gastric cancer: a systematic review of literature by the Task Force of the Japanese Gastric Cancer Association. Gastric Cancer, 17(1), 26-33.

6. Lê Thành Trung (2011), Đánh giá hiêu quả điêu trị ung thư da dày di căn hach bằng phẩu thuật triệt căn kết hợp hóa chất bổ trợ tại bệnh viện $\dot{K}$, Luần văn thạc sỹ Y hocc, Trường Đại học Y Hà Nội.

7. Trịnh Thị Hoa (2009), Đánh giá hiệu quả của hoá trị bổ trở ECX trên bênh nhân ung thư biểu mô tuyến dạ dày sau phẫu thuật tại bệnh viện $K$ (2006-2009), Luận văn thạc sĩ Y học, Trường Đại hoc Y Hà Nối.

8. Trịnh Hồng Sơn (2001), Nghiên cứu nạo vét hach trong điều trị phẫu thuật ung thư dà dày, Luận án tiến sỹ Y khoa, Trường Đại học Y Hà Nội.

\section{NGHIÊN CỨU ĐĂC ĐIỂM LÂM SÀNG, CÂNN LÂM SÀNG VÀ KẾT QUẢ SỚM ĐIỀU TRI PHÌNH ĐộNG MACH CHỦ BỤNG DƯỚI THÂ̂N BẰNG CAN THIỆP NộI MACH}

\section{TÓM TẮT}

Giới thiêu: Phình đông mạch chủ bung là tình trang giãn lớn khu trú một đoạn động mạch chủ bụng với đường kính được xác định tại vị trí có phình lớn hơn 1,5 lần đường kính đoạn động mạch chủ bụng bình thường. Túi phình động mạch chủ bụng lớn đần theo thời gian và diễn tiến đến võ phình với nguy cơ tử vong cao nếu bênh không đước chẩn đoán và điều trị kịp thời. Can thiệp nội mạch đặt ống ghép đã được ứng dung rônng rãi trên thế giới cho thây tính an toàn và hiệu quả cao trong điều trị phình động mạch chủ bung. Muc tiêu: Nghiên cứu này được thực hiện nhằm khảo sát một số đặc điểm lâm sàng, cận lâm sàng và đánh giá kết quả sớm ứng dụng kỹ thuật can

*Bệnh viện Chợ Rẫy

**Đai hoc Y Dước Thành phố Hồ Chí Minh

Chịu trách nhiệm chính: Nguyễn Văn Quảng

Email: drquangptmmcr@gmail.com

Ngày nhận bài: 19.01.2021

Ngày phản biên khoa hoc: 18.3.2021

Ngày duyệt bài: 30.3.2021

\section{Nguyễn Văn Quảng*, Trần Quyết Tiến**}

thiệp đặt ống ghép nội mach điều trị phình động mạch chủ bụng dưới thận. Đối tượng và phương pháp nghiên cứu: Nghiên cứu mồ tả dọc tiến cứu. Đối tượng là bệnh nhân phình động mạch chủ bụng dưới thẩn có kèm hoặc không kèm theo phình động mach chậu tại khoa Phẫu thuâat Mạch máu Bệnh viện Chợ Rẫy, trong thời gian từ tháng $5 / 2012$ đến tháng 8/2017 được điêuu trị bằng phương pháp can thiêp nội mạch. Kết quả: Có tất cả 95 trường hợp (71 nam và 24 nữ) đủ tiêu chuẩn đưa vào nghiên cứu. Tuổi trung bình là $73,8 \pm 17,6$ tuổi.Triệu chứng lâm sàng phổ biến là đau bụng $(62,1 \%)$ ). Yếu tố nguy cơ và bệnh kèm phổ biến là tăng huyết áp, hút thuốc là và rối loan lipid máu. Đa số túi phình là hình thoi, đường kính trung bình là $59,9 \pm 15,1 \mathrm{~mm}$. Tỷ lệ thành công về măt kỹ thuật là $98,9 \%$. Biến chứng thường gặp nhất là tụ máu vết mổ $(11,6 \%)$. Tỷ lệ tứ vong sớm là $1,1 \%$ xảy ra ở 1 bênh nhân nhồi máu cơ tim trong giai đoạn hậu phẫu. Kết luận: Phình động mạch chủ là bênh lý nguy hiểm và thường gắp ở người lớn tuổi. Can thiệp đặt ống ghép nội mạch cho thấy tính ít xâm lấn, an toàn và hiệu quả trong điều trị phình động mạch chủ bụng dưới thận. 